\title{
Some Notes On an Active Service Kit and Equipment
}

\section{Captain R. M. G. Tulloch}

To cite this article: Captain R. M. G. Tulloch (1904) Some Notes On an Active Service Kit and Equipment, Royal United Services Institution. Journal, 48:322, 1410-1414, DOI: 10.1080/03071840409418644

To link to this article: http://dx.doi.org/10.1080/03071840409418644

$$
\text { 曲 Published online: } 11 \text { Sep } 2009 .
$$

Submit your article to this journal $\sqsubset$

LII Article views: 6 


\section{SOME NOTES ON A ACIIVE SERVICE KIT AND EQUIPMENTT.}

By Captain R. M. G. TULIOCH, 2nd Royal West Tent Regiment.

THE following notes are put together, not with the, idea of expounding new ideas, but to impress and recall certain useful information learnt after many uncomfortable days and nights on service in South Africa. Looking back, even after a few weeks on service, officers seem to be quite different beings to those who landed fresh from shipboard, hung about with many and curious articles, half of which were discarded after the first fow days. Apart from not knowing exactly what to take and what not to take, both in the kit and on the person, the absolute want of knowledge of both officers and men of how to make themselves comfortable and to make the best of the things available, when in the open, away from towns or houses and the ordinary routine of peace life, was absolutely pitiable; and in these notes it is hoped to give some information which may save others from like misfortunes.

The first point impressed on the writer was that it is far better to take too much kit and to shed it, preferably, if possible, at some depôt, to be picked up later, as opportunity offered or occasion required, than to start with too little, and be in want of such needful articles as blankets or an oil-sheet, and have to go without for months. This may sound an extravagant idea; but as on active service everything must be of the very best, the cost of the extra articles is money well spent, and later, when up at the front, untold wealth will not buy any needful articles that are deficient.

It may have been that after the first few marches, officers and men were more accustomed to the work, and knew what to expect; but certain it is that the first marches, bivouacs, and outposts were far more uncomfortable and unpleasant in cvery way than subsequent ones, and it can only be thought that, as time went on, everybody learnt how to look after themselves, even under very adverse circumstances, which is a secret well worth knowing.

On disembarkation, officers were too much inclined to carry all manner of arms, equipment, etc., on the person, quite forgetting that active service means weeks and often months of marching, with but an occasional fight thrown in. After a lengthy period of trekking, it was found that the most comfortable, light, and at the same time useful, articles were field glasses, walking stick, haversack, water bottle, sweater (or even sweater and Cardigan jacket), and revolver. Taking the utility of these articles in detail, the field glasses were far and away the most important part of the officer's kit, certainly as regards the men under his command, as an officer with good glasses is the look-out man, and, so to speak, the eye of the company. A haversack is not a necessity, but is at the same time most useful for 
SOME NOTES ON AN ACTIVE SERVICE KIT AND EQUIPMENT. 1411

carrying odds and ends and the very necessary reserve of a biscuit or two and a piece of chocolate. A water bottle in all cases is a necessity. $\Lambda$ sweater may sound a curious article of kit to carry about, but in South $\Lambda$ frica, where the temperature fell immediately at sundown, it was most useful, being light and very warm; and from the writer's experience, if the body were kept warm, it was possible to sleep under nearly any circumstances, even though damp. An oil sheet was not carried on the person, and in place of a sweater a blanket was found to be the next best covering, as it is preferable to be warm, even if damp, in which case sleep is possible, rather than dry, but cold, when sleep is out of the question.

The weapon for an infantry officer is preferably a revolver, as it is very handy for night use when on patrol, or when visiting sentries. By day an officer hardly ever needs a weapon, as he should not want to be in the firing line shooting, but rather controlling it, and using his glasses; and if at last there comes a charge, by that time there are plenty of dead and wounded from whom to get a rifle and bayonet.

Waterproofs, or oil sheets as they are usually called, are a most useful article in a campaigner's kit, as, wrapped in a big waterproof sheet, everything is kept dry, however bad the rain; and perhaps the best are those of Willesden canvas, as they stand rough wear very well, and there is no rubber to peel off, as in some kinds. The sheet itself should be of a good size, so as to cnable the owner to completely roll himself up in it.

During the later stages of the South African War, when on outpost, the bed valise was never taken out, but only a couple of blankets rolled in a big waterproof sleet so as to save transport, which was especially necessary when the picket was on a hill-top. There are many good patterns of bed valise, those that have a flap coming over being the best. Some patterns lace down the centre, but are most uncomfortable when it rains, as the rain leaks in through the centre seam unless pulled very tight, and if laced too tightly it is impossible to get out in a hurry. It is not at all pleasant being laced up tightly in a bed valise, and knowing that if any alarm occurs it is impossible to get out rapidly; and as on outpost it would not be safe to lace it up tight, on a wet night the owner would be soaked.

As regards food, a sound maxim is to eat whenever possible, as it is never known when the next meal can be obtained; and a reserve carried on the person in a haversack or jacket pockets when marching is an absolute necessity. It was found that two or three ration biscuits and a piece of clocolate were about the most sustaining and portable means of subsistence, as they were light, not easily broken up (except the chocolate, which should be carried in a small tin), and most sustaining, the chocolate and the biscuits being very "filling," whereas in the patent lozenges, often recommended, there is plenty of sustenance, but they do not at all give the feeling inside that a solid meal has been taken. The great idea to keep in mind when on the march is to go as lightly equipped as possible, in order to get over the ground comfortably, and yet have sufficient on the person so as to be independent, if necessary, of the waggons for twenty-four hours.

Owing to the want of firewood in the Free State, the men were accustomed to carry their firewood-a few sticks or a picce of woodfor miles, knowing that if they did not, on arrival in camp they wouid have nothing to cook with, and so would go to sleep hungry. In

vol. XLVIII:

$4 x$ 


\section{SOYE NOTES ON AN ACTIVE SERVICE FIT AND EQUIPNENT.}

the division with which my regiment worked, at one period the men received a daily issue of flour instead of biscuit, and consequently had to do the cooking of chupattics for themselves, and those who had no sticks or did not understand cooking came off badly.

This habit of laying in a store for the future and making preparations for the next day was soon impressed on the men, for the reason just stated, and was a most useful training for men who had always before been in the habit of getting just what they wanted for the asking from a shop or from the canteen. Whenever there was a chance, the men used to lay in stores of Quaker Oats, etc., and the moment a march was done they fell out, collected any cowdung available, or used the sticks they had brought with them, and in a few minutes there were dozens of little fires going; and these small messes of two or three had something cooked and eaten long before the company teas were ready. Later in the war, when sheep and cattle were killed as extra rations, it was no uncommon sight to see men marching along with picces of cooked or raw meat, and even legs of mutton, hung on their equipment, so that on arrival in camp they had food ready, and this habit of self-support of looking after himself was one of the best things learnt by the infantry soldier in South Africa.

As an example of how, at first, men did not look after themselves: I was once sent with a new draft from England-not of my own regiment-to hold a detached post near Blocmfontein. After having been camped on arrival for about an hour, $I$ inquired why there was no cooking, and was told the men had no wood, and was asked where they might get it, though there was plenty of good firewood only a few hundred yards away. And even though the men had plenty of money, not one of them thought of purchasing fowls, eggs, or even bread, from a native village near by, but lived on their bare rations.

In all cases the ignorance of how to look after themselves was simply because they had always lived in towns, and had never before been told about such matters, or even thought of them for themselves.

In this article reference is only made to infantry officers and men; the mounted troops were much better off than those on foot, as they could carry more with them, and had a wider field to forage over.

The writer was much impressed with the necessity of officers knowing something of cooking, as often when one or two companies were detached, the officers had to trust to the efforts of an unskilled private, and the results were frequently somewhat surprising, though taken all round they were not bad. Still, even an elementary knowledge of cooking would have been most useful on many occasions.

When a force is halted, even for a short time, it is wonderful what good temporary ovens can be made out of ordinary corrugated iron, and these ovens are a great blessing to all ranks, as flour, if obtainable, can be made into bread easily, and also a variety is given to the cooking. In referring to these temporary ovens, big ones, as used by the A.S.C., are not meant, but small ones for 6 or 8 men, roughly put together by untrained men.

In a bivouac the men learn very quickly to club two or three together and make a rough shelter tent of two blankets and a waterproof sheet supported by rifles, using the remaining blankets and waterproof sheets inside to sleep on. The bivonac can be much improved by sods piled round the bottom cdge of the roof to keep out both the wind and surface water. In a bivouac, or even a long halt 
by day in a hot sun, a blanket supported on rifles or sticks to keep orf the sun is a necessity, as without shade, sleep in comfort is quite impossible, and lying in a hot sun is not much rest, and is deciaedly daugerous.

As marching occurs far oftener in a campaign than fighting, good and comfortably fitting boots and plenty of spare socks and boot laces are a most important part of a useful kit. Two good pairs of boots, well dubbed, and plenty of spare laces are absolute necessities. Laces come in most useful, not only for one's boots, but for tying up shelter tents, etc., and a hundred and one odd things, when string io not procurable. However good and comfortable boots may be, if they have no laces, or only half a one, they are not at all pleasant to walk in. As the weight of the kit is limited, it is impossible to take large quantities of socks, boot laces, soap, cigarettes, chocolate, and other articles which require frequent replenishing, and so a good system is to arrange with friends at home to send out by parcels post weekly or fortuightly such articles as soap, chocolate, and cigarettes, and, say, once a month, a flannel shirt, pair of socks, and boot laces. Of course, certain things may get lost in the post, but those that do arrive are worth their weight in gold, and if not wanted by the receiver, are always most useful to someone. On the march, during any long halt, it is an excellent thing to take off putties, boots, and socks, and let the socks dry in the sun while resting the feet; but care must be taken not to lie with the feet too much in the sun, or they will get badly burnt, and marching will then be agony.

At the present time every sort of tinned provision is obtainable, and if transport suffices there is not likely to be any danger of running short of food over and above the ordinary rations; but if, as is generally the case, transport is not available, then the provisions must be the least bulky and the most useful obtainable. Fancy tinned stuffs must be rigorously excluded, and the commonplace but useful tiuned provisions, such as tongues, herrings, sausages, etc., carried instead.

In a campaign, disease causes far greater loss than the weapons of the enemy, and any check that can be used to prevent the outbreak of disease must be employed to its fullest extent. Boiling and filtering all drinking water is recognised as one of the best preventatives; but these simple and effective remedies must be proporly employed. It is often the case that men do not boil the water sufficiently, owing to being in a hurry, and the moment it commences to simmer they remove it from the fire without allowing it to really boil for a minute or two. The filters issued to the troops are good; but the " pocket filters," often bought for use on service, are generally very heavy and quite useless for filtering purposes. They may clear a certain amount of sediment from the water, but that is about all they do, and to trust to them instead of boiling the water is absolute folly.

Below is given a rough list of what is required for a service kit, but it must be remembered that the details vary according to what part of the world the campaign takes place in, and moreover, the total weight of the articles mentioned in the accompanying list far exceeds the regulation allowance. As before stated, it is better to have too much, and consequently to have to shed articles when transport fails. Such kit can generally be left at some central point and recovered later, when it comes in, perhaps, exceedingly useful.

$$
4 \times 2
$$


1414 SOME NOTES ON AN ACTIVE SERVICE HIT AND EQUIPMENT.

The articles of underclotling mentioned should all be of wool, preferably Jäger clothing, as wool is warmer and lighter in proportion than any other material, and; if good, wears exceedingly well. In conclusion, the main points of these notes may be summed up as follows;-Have a good and useful kit to start with; eat and sleep whenever you get an opportunity; and learn how to make yourself comfortable under the most unfavourable conditions.

The following is a list of the most necessary articles required:-

1 bed valise.

1 large waterproof sheet (say 6 feet by 4 feet).

1 folding lamp (with talc sides).

I canvas bucket.

2 changes underclothing (wool).

1 change uniform.

1 pair spare boots.

4 pairs socks.

6 handkerchiefs.

Boot laces.

Writing materials.

Washing materials.

Balaclava cap.

Sweater.

Great-coat.

Gloves (woollen).

Canvas shoes or slippers.

Blankets (two or more).

Soap.

Chocolate.

Dubbin.

Candles.

Matches.

A small folding camp bed and cork mattress are useful, but these could only be brought up from the base if the force is halted for a long period, or when guarding lines of communication. 